\title{
28. STRUCTURE AND EVOLUTION OF BAHAMIAN DEEP-WATER CHANNELS: INSIGHTS FROM IN-SITU GEOPHYSICAL AND GEOCHEMICAL MEASUREMENTS ${ }^{1}$
}

\author{
Colin F. Williams, ${ }^{2}$ Roger N. Anderson, ${ }^{2}$ and James A. Austin, $\mathrm{Jr}^{3}$
}

\begin{abstract}
Two studies of well logs from Leg 101 of the Ocean Drilling Program provide new information concerning the underlying structure of Bahamian deep-water channels. In the first study, subsidence calculations (based upon porosity and lithology logs from Site 626 in the Straits of Florida and oil tests located at Palm Beach, Key Largo, and Great Isaac Island) confirm the substantial (tens of kilometers) westward progradation of Great Bahama Bank, suggested by Austin, Schlager, et al. (1986). This progradation may have been going on since the late Oligocene. Subsidence calculations also show a consistent subsidence rate for the region in question, supporting the existence of a large Lower Cretaceous shallow-water carbonate platform underlying the northwestern Bahamas. In the second study, mineralogical information from an induced gamma spectroscopy log (GST) at Site 634 in Northeast Providence Channel was used to generate synthetic seismograms of the penetrated section. These seismograms accurately reproduce two reflectors visible on a nearby seismic line, tying these reflectors to specific depths and lithologies in the penetrated formation. Results of both studies illustrate that because physical properties of carbonate environments are facies-dependent, accurate geophysical models of these environments require detailed, site-specific measurements.
\end{abstract}

\section{INTRODUCTION}

Leg 101 of the Ocean Drilling Program was the inauguration of the first permanent logging program in deep-sea drilling history. Despite unstable hole conditions, through-pipe well logging was completed successfully in Hole 626D (Straits of Florida) and in Hole 634A (Northeast Providence Channel) (Fig. 1). We report here the results of two studies that developed from these well-logging measurements. These studies not only provide new information about the geologic structure and history of the Bahamas but also illustrate two methods by which geophysical logs (when combined with data from drilling records and site surveys) can contribute insights into geological problems beyond simple characterizations of the physical properties of penetrated formations.

In the first study, in-situ porosity measurements from Hole $626 \mathrm{D}$ and from three exploratory oil tests are the basis for examining the post-Oligocene subsidence of the Straits of Florida and neighboring banks. This subsidence then is evaluated in terms of possible structures underlying the Straits of Florida and lateral migration of flanking carbonate banks. The second study describes the development of a new synthetic seismogram technique using geochemical well logs to generate a quantitative evaluation of impedance changes with depth. This technique is applied to logs from Hole 634A, providing correlations of prominent reflectors on an adjacent multichannel seismic line with specific depths and ages in the hole.

\section{THE BAHAMAS CONTROVERSY}

Distribution and orientation of Bahamian carbonate banks and deep-water channels clearly are controlled by some combination of underlying basement structures and ancient sedimentary processes. The nature of these underlying structures and the degree to which they influenced the development of the mod-

\footnotetext{
${ }^{1}$ Austin, J. A., Jr., Schlager, W., et al., Proc. ODP, Sci. Results, 101: College Station, TX (Ocean Drilling Program).

2 Borehole Research Group, Lamont-Doherty Geological Observatory, Palisades, NY 10964.

${ }^{3}$ Institute for Geophysics, University of Texas, 8701 Mopac Boulevard, Austin, TX 78759-8345.
}

ern Bahamas were the subject of a number of studies (e.g., Meyerhoff and Hatten, 1974; Tator and Hatfield, 1975; Mullins and Lynts, 1977; Schlager and Ginsburg, 1981; Sheridan et al., 1981). Questions about the processes that created the Bahamian deep-water channels lie at the heart of the debate over two popular hypotheses for the origin of the Bahamas-the graben and the megabank hypotheses (Austin, Schlager, et al., 1986). The graben hypothesis holds that horst and graben structures, created by rifting that accompanied the initial formation of the Atlantic, underlie the modern Bahamian banks and channels, respectively, and provide nearly complete tectonic morphological control (Mullins and Lynts, 1977). The megabank hypothesis attributes today's arrangement of banks and channels to differential growth and subsidence after a mid-Cretaceous(?) drowning of an extensive shallow-water carbonate platform province. This province may have extended from the Bahamas across southern Florida to northern Cuba and the Gulf of Mexico (see Schlager and Ginsburg, 1981). The differences between these two hypotheses illustrate the division of Bahamas theorists into two groups, with one group emphasizing the importance of erosional and depositional processes and the other group relegating these processes to a superficial role in affecting tectonically derived structures.

Leg 101 was drilled to supplement earlier studies and to acquire new information about the formation and structure of the Bahamian deep-water channels. At the beginning of Leg 101, we hoped that two successful penetrations of reflectors (thought to represent the top of the drowned megabank) would provide a clear, unambiguous solution to the problem of the Bahamian structural evolution. During events that have been documented elsewhere (Austin, Schlager, et al., 1986), drilling penetrated the top of a shallow-water carbonate platform only at Site 627, north of Little Bahama Bank (Fig. 1). This single penetration left open the question of whether the modern Bahamas lie atop a buried mid-Cretaceous megabank or are composed of a series of isolated carbonate banks, each with its own growth and submergence history. Although Eberli and Ginsburg (1987) recently established that the post-Cretaceous structure of Great Bahama Bank is characterized by a set of banks whose margins have migrated laterally many kilometers, further correlation of Leg 101 drilling results with data from other locations on the banks and in the channels is required to clarify the pre- and post-Creta- 


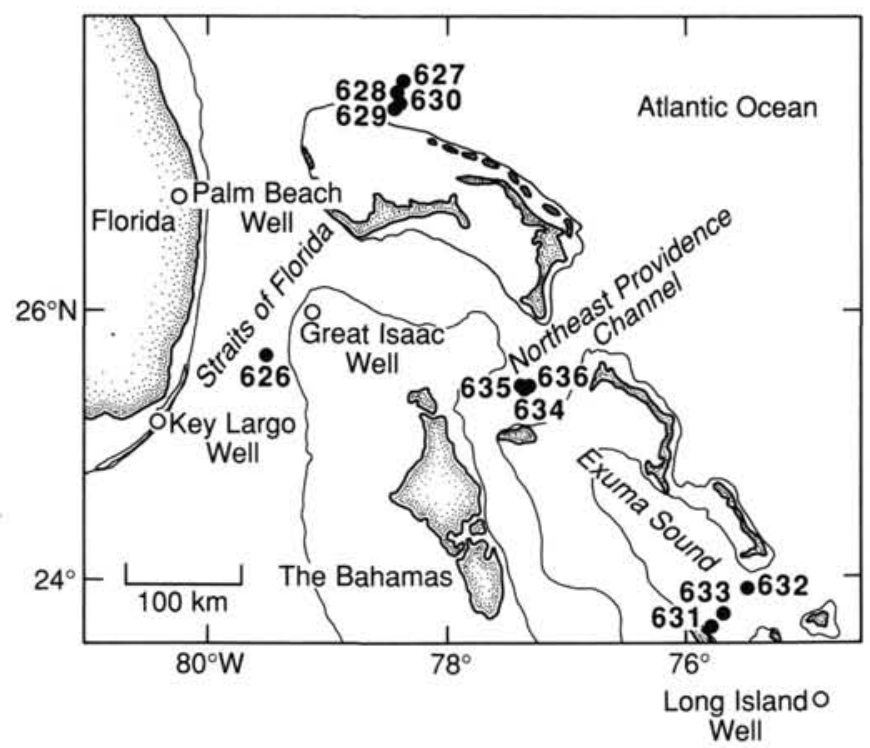

Figure 1. Location map of Leg 101 sites and nearby exploratory wells in the Bahamas.

ceous history of the Bahamas. Here, we focus on approaches for establishing the validity of seismic ties among various deep penetration sites in the northwestern Bahamas, thereby constraining their structure and evolution.

\section{LOG-DERIVED SUBSIDENCE AND STRUCTURE OF THE STRAITS OF FLORIDA}

Site 626 , located in the eastern half of the Straits of Florida between Miami and the Bimini Island group (Fig. 1), was drilled with the intention (1) of penetrating the top of the drowned mid-Cretaceous(?) shallow-water carbonate platform and (2) of documenting the history of local Gulf Stream flow (Austin, Schlager, et al., 1986). Although drilling operations had to be suspended before reaching our desired goals, the proximity of oil test wells on either side of the straits and seismic-jump correlations of those wells with Site 626 allowed us to study the structure and evolution of the straits and bounding banks.

Well logs and stratigraphic columns from three deep wells that border the northern Straits of Florida (the Key Largo well, drilled to $3649 \mathrm{~m}$ by the Sinclair Oil \& Gas Co.; the Palm Beach well, drilled to $4078 \mathrm{~m}$ by the Humble Oil \& Refining Co.; and the Great Isaac well, drilled to $5441 \mathrm{~m}$ by the Bahama California Oil Co.) and data from Site 626 were used for this study (Furrazola-Bermudez et al., 1964; Maher, 1965; Tator and Hatfield, 1975; Schlager et al., this volume). The Key Largo and Palm Beach wells penetrated shallow-water limestones and dolomites of Early Cretaceous/Late Jurassic age (Maher, 1965). The Great Isaac well passed through this carbonate section to bottom in Lower Jurassic/Upper Triassic(?) volcaniclastics (Tator and Hatfield, 1975; Schlager et al., this volume). Stratigraphic control and well-logging information are poor in the upper sections of these wells, as the main drilling objectives involved the location of deep oil-bearing formations.

In contrast to the deep penetration and uncertain stratigraphic control of these Bahamas oil tests, the deepest of the four holes drilled at Site 626 (Hole 626D) penetrated only $447 \mathrm{~m}$ below the seafloor. However, this hole yielded a detailed age-depth sequence. Shipboard studies identified three lithologic units, composed mostly of carbonate contourite sand, debris flows, and turbidites (Fig. 2; Austin, Schlager, et al., 1986). The logging program for Hole 626D used Schlumberger neutron porosity (CNT-G) and natural-gamma-radiation (GR) tools. Figure 3 shows the corrected logs from Hole 626D. Corrections were applied for borehole size, eccentricity of the tool string, and attenuation caused by the presence of the drill pipe. These logs depict a number of oscillations in porosity, most likely from alternating hard and soft layers in the formation. However, despite these oscillations, a consistent decrease in porosity of approximately $25 \%$ over the length of the hole occurs with depth.

To develop geological models from Hole 626D logs, postcruise $\log$ analysis involved examining the subsidence of the Straits of Florida and relating that subsidence to structures underlying and bounding the straits. If the straits formed as a result of erosional and depositional processes modifying a Cretaceous megabank, then predictable observations should follow after calculating the subsidence rates at Sites 626 and the Great Isaac, Palm Beach, and Key Largo wells. First, when corrected for varying post-Cretaceous sedimentation rates, subsidence rates on either side of the Straits of Florida should be about the same. Second, subsidence at Site 626 should be slightly greater than that predicted by sediment loading and compaction alone. This follows from the supposition that the underlying megabank is subsiding at a regionally uniform rate. This rate should be controlled by larger sediment loads on the banks, causing the deep-water channels to show a steadily increasing deviation from the local isostatic equilibrium predicted by deep-water sediment loading. If the straits are underlain by a grabenlike structure, motion along the faults that formed the straits may have ceased more than 100 m.y. ago, and the presence of these faults might not show up during recent subsidence history. However, if these faults were active during the time covered by the subsidence data, then the subsidence record at Site 626 should clearly indicate fault motion.

Figure 4 shows the uncorrected sedimentation-rate/subsidence curves for Site 626 and the Great Isaac, Key Largo, and Palm Beach wells. Palm Beach and Key Largo display almost identical subsidence patterns, while the subsidence at Site 626 is about $150 \mathrm{~m}$ greater since the beginning of the late Oligocene. Over the same interval, the subsidence at Great Isaac is greater by more than a factor of 3 than that at the other sites. Thus, it appears that subsidence on the eastern side of the straits increased more than that on the western side. However, this increased subsidence at Great Isaac may simply have been caused by greater sedimentation rates. The backstripping analysis that follows provides conclusive information about tectonically driven variations in subsidence rates.

Backstripping is a standard method for examining the subsidence history of a well and for determining what part of the subsidence is caused by forces other than sediment and water loading (Van Hinte, 1978; Steckler and Watts, 1978; Watts et al., 1982). By using a model of local isostatic equilibrium, backstripping can measure the depth to basement (or a predefined datum level), $Y$, in the absence of surface loads. This value is derived by the equation,

$$
Y=S^{*}\left[\left(\rho_{m}-\rho_{s}\right) /\left(\rho_{m}-\rho_{w}\right)\right]+W_{d}-\Delta_{s l}\left[\rho_{m} /\left(\rho_{m}-\rho_{w}\right)\right],(1)
$$

where $S^{*}$ is the sediment thickness, $W_{d}$ is the water depth, $\Delta_{s l}$ is the change in sea level over the interval under consideration, $\rho_{m}$ is the mean mantle density, $\rho_{s}$ is the mean sediment density, and $\rho_{w}$ is the mean water density.

To conduct a backstripping analysis of subsidence, three requirements must be satisfied. First, a reliable biostratigraphic record spanning the time and depth of interest must exist to establish accurate sedimentation rates. Second, there must be an accurate description of the variation of porosity (and, thus, also density) with depth, so that the amount of compaction with burial can be accounted for in the backstripping calculations. Third, the relative changes in water depth during the time in question must be estimated. These changes act as differential 


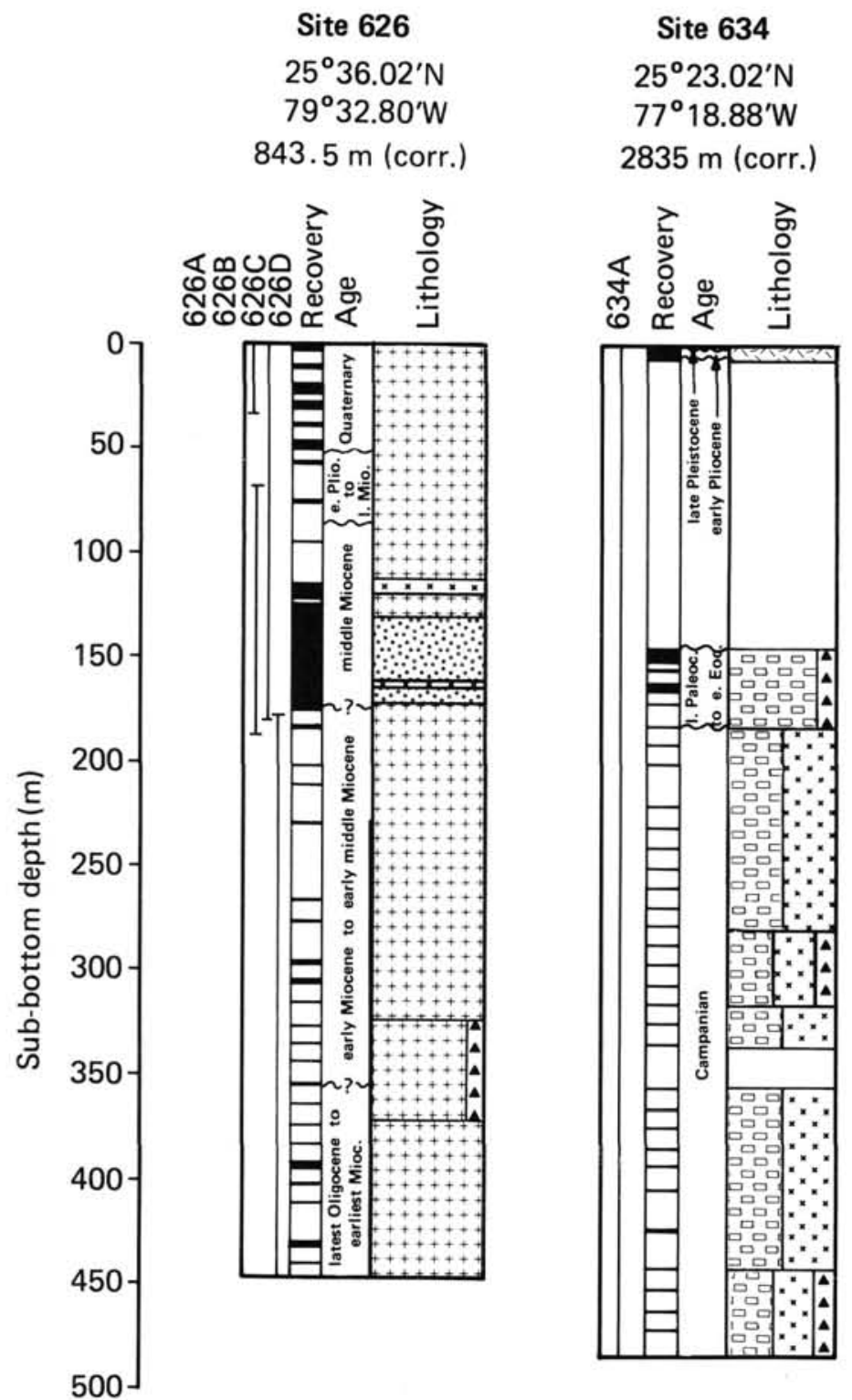

KEY

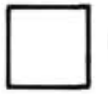
Unrecovered interval

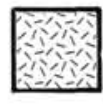

Periplatform ooze

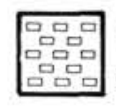

Pelagic calcareous ooze and chalk
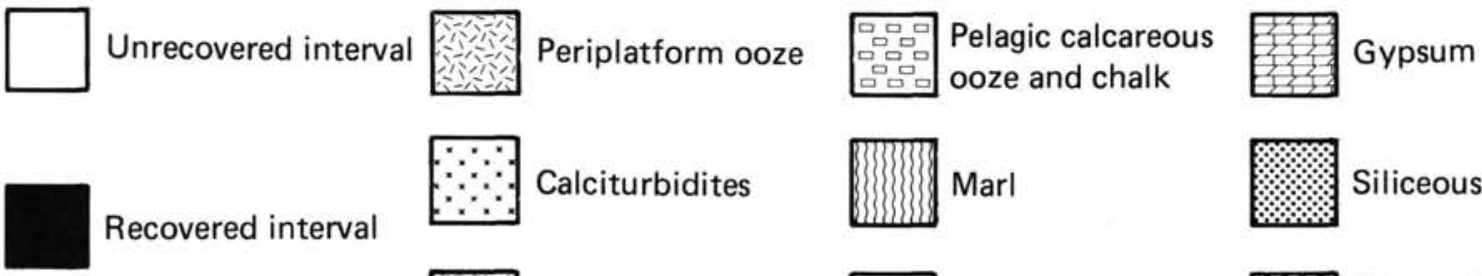

Recovered interval

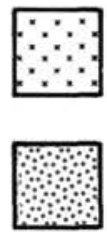

Calciturbidites
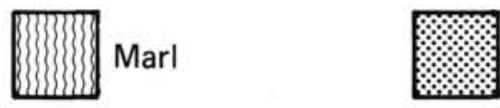

Siliceous limestone

Debris flows

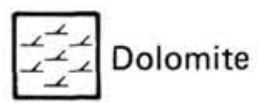

Glauconitic/phosphatic calcisphere limestone

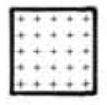

Winnowed calcareous sand

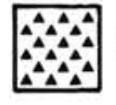

Chert

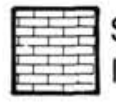

Shallow-water limestone

Figure 2. Lithologic and biostratigraphic section from Site 626 in the Straits of Florida and Site 634 in the Northeast Providence Channel. After Austin, Schlager, et al. (1986). 

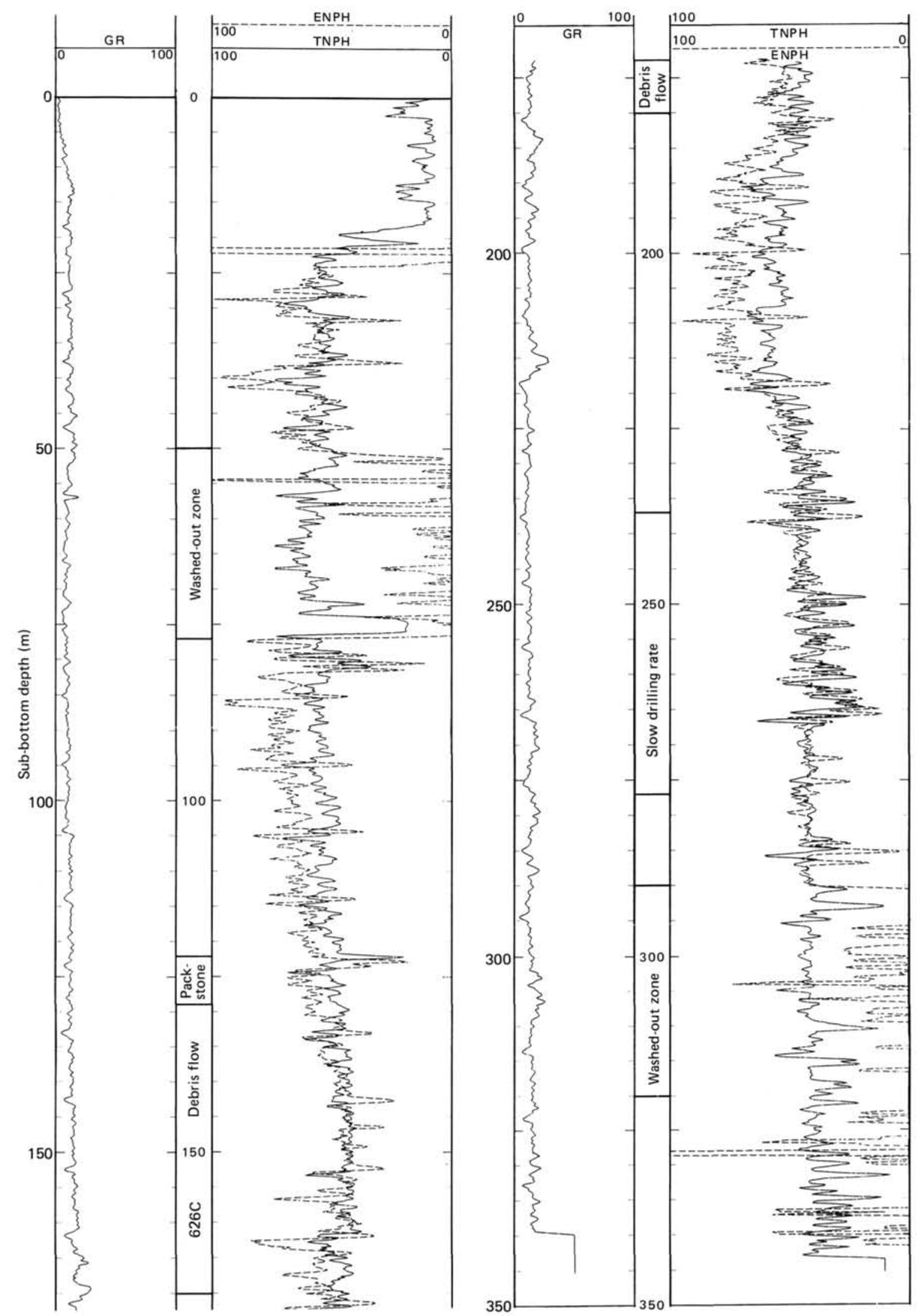

Figure 3. Neutron-porosity and gamma-ray logs from Hole 626D, with a typical pipe-collar response and prominent lithologies from Hole $626 \mathrm{C}$ indicated. The curve labeled $T N P H$ (solid line) represents the thermal-neutron porosity measurement used in the compaction correction. ENPH, epithermal neutron porosity. Natural gamma radiation is given in standard API units. 


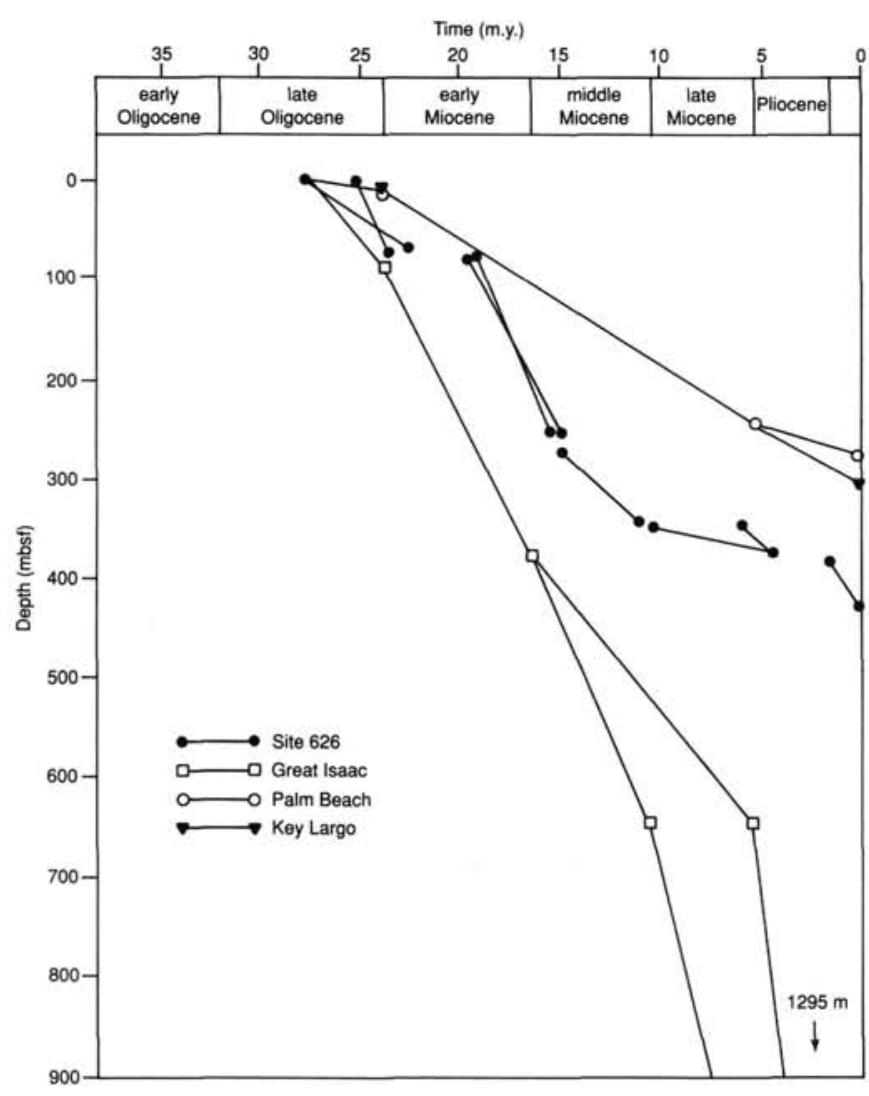

Figure 4. Subsidence curves for Site 626 and the Great Isaac, Palm Beach, and Key Largo wells. The indication of two ages in the Great Isaac well at the same depth represents uncertainty in the Miocene section of the well.

loads on the system and must be corrected for; otherwise, results can lead to erroneous conclusions about tectonic histories.

Near the Straits of Florida, biostratigraphic information is available as follows. At Site $\mathbf{6 2 6}$ detailed sedimentation-rate information exists back to the late Oligocene (Austin, Schlager, et al., 1986). Schlager et al. (this volume) provide a fairly complete section throughout the entire Great Isaac well; at the Key Largo and Palm Beach wells less detailed sections exist (Maher, 1965; Sheridan et al., 1981). The limited penetration at Site 626 required that, for our comparisons, subsidence analyses cover only the span of time since the late Oligocene.

For correction of compaction, there is detailed control of porosity with depth from well logs in Great Isaac and Hole 626D, along with a regional porosity-vs.-depth function developed for South Florida by Schmoker and Halley (1985) from a study of 15 oil and water wells (including wells near Key Largo and Palm Beach). In carbonates, chemical diagenesis often alters porosity by an amount equal to or greater than that resulting from physical compaction. The Bahamas are no exception, as indicated by the cavernous limestone porosity at great depths in an exploratory well on Andros Island (Spencer, 1967; Goodell and Garman, 1969). Although diagenesis is a function of both time and depth, the porosity distributions found by Schmoker and Halley are strong functions of depth and only weak functions of age. Schmoker and Halley determined that, for the South Florida region, the relationship,

$$
\text { Porosity }=51.3 \exp (-0.000518 z),
$$

accurately described the regional change in porosity of limestone with depth $z$ (in meters) and that the relationship,

$$
\text { Porosity }=30.4 \exp (-0.000217 z) \text {, }
$$

described the change in porosity of dolomite with depth $z$ (also in meters). Thus, Schmoker and Halley concluded that compaction is an important effect to great depths for both dolomites and limestones and must be included in any accurate subsidence calculation. In contrast, Freeman-Lynde et al. (1981) in their study of the subsidence of Andros Island and the Bahama Escarpment concluded that full compaction of shallow-water carbonates occurs within a few meters of the surface and thus can be ignored in subsidence calculations.

The apparent conflict between these two approaches can be resolved by considering facies-dependent effects. Figure 5 displays Schmoker and Halley's limestone curve, along with corrected neutron porosity logs from the Great Isaac and Long Island wells. Penetrating a shallow-water carbonate "reef-backreef" facies similar to that encountered on Andros Island, the Long Island well (Meyerhoff and Hatten, 1974) provides a valuable check on the nature of compaction in the shallow-water carbonates studied by Freeman-Lynde et al. (1981). As Figure 5 shows, porosity in the Long Island well follows Schmoker and Halley's limestone curve, except for the section above $700 \mathrm{~m}$. No neutron porosity logging information is available for the upper $1500 \mathrm{~m}$ of Great Isaac; however, other porosity-dependent logs (such as sonic [Fig. 5] and resistivity) clearly indicate that shallow porosity in the Great Isaac well, unlike the Long Island well, follows Schmoker and Halley's curve. Apparently, compaction trends in these carbonates vary by region, which means site-specific data must be analyzed before proceeding with any general compaction model. Because of the successful fit shown in Figure 5 and the accuracy of the fit for South Florida, Schmoker and Halley's limestone curve was applied to the Key Largo, Palm Beach, and Great Isaac wells. Because of lower sedimentation rates, the relevant section at Site 626 is much thinner, making Schmoker and Halley's fit from a greater depth range less accurate. For Site 626 , the relationship,

$$
\text { Porosity }=56.0 \exp (-0.00096 z) \text {, }
$$

matched the porosity of Hole 626D more accurately than Schmoker and Halley's relationship. The curve-fit is shown in Figure 6.

Determining the relative change in sea level during the time period in question requires a detailed paleoenvironmental record at each site. This type of data was not available for the Straits of Florida sites; thus, in our first approximation, relative sea-level correction was left out of our backstripping equations. This had two important consequences. First, the computed subsidence rates did not include the effects of eustatic sea-level changes; but as our analysis was only for relative differences in subsidence at four sites in the region, the offsets introduced by eustatic corrections should not alter results. Second, our approximation required us to assume that relative water depths remained constant among the sites. This, in turn, implies the absence of significant bank progradation and erosion. The validity of this assumption for the Great Isaac well is an important question in the discussion of the following results.

The four sedimentation-rate curves were backstripped using Steckler and Watts' (1978) method (discussed previously), yielding "tectonic" subsidence rates. The porosity relationships given previously and a simple compaction model,

$$
h_{i}\left(1-\phi_{i}\right)=h(1-\phi),
$$

were applied. This model relates the compacted thickness $(h)$ of a given sediment layer (original thickness, $h_{i}$ ) to the change in porosity $\left(\phi_{i}\right.$ to $\left.\phi\right)$ on compaction. Figure 7 shows these backstripped subsidence curves. The "tectonic" subsidence rates at Site 626, Palm Beach, and Key Largo are about the same; how- 

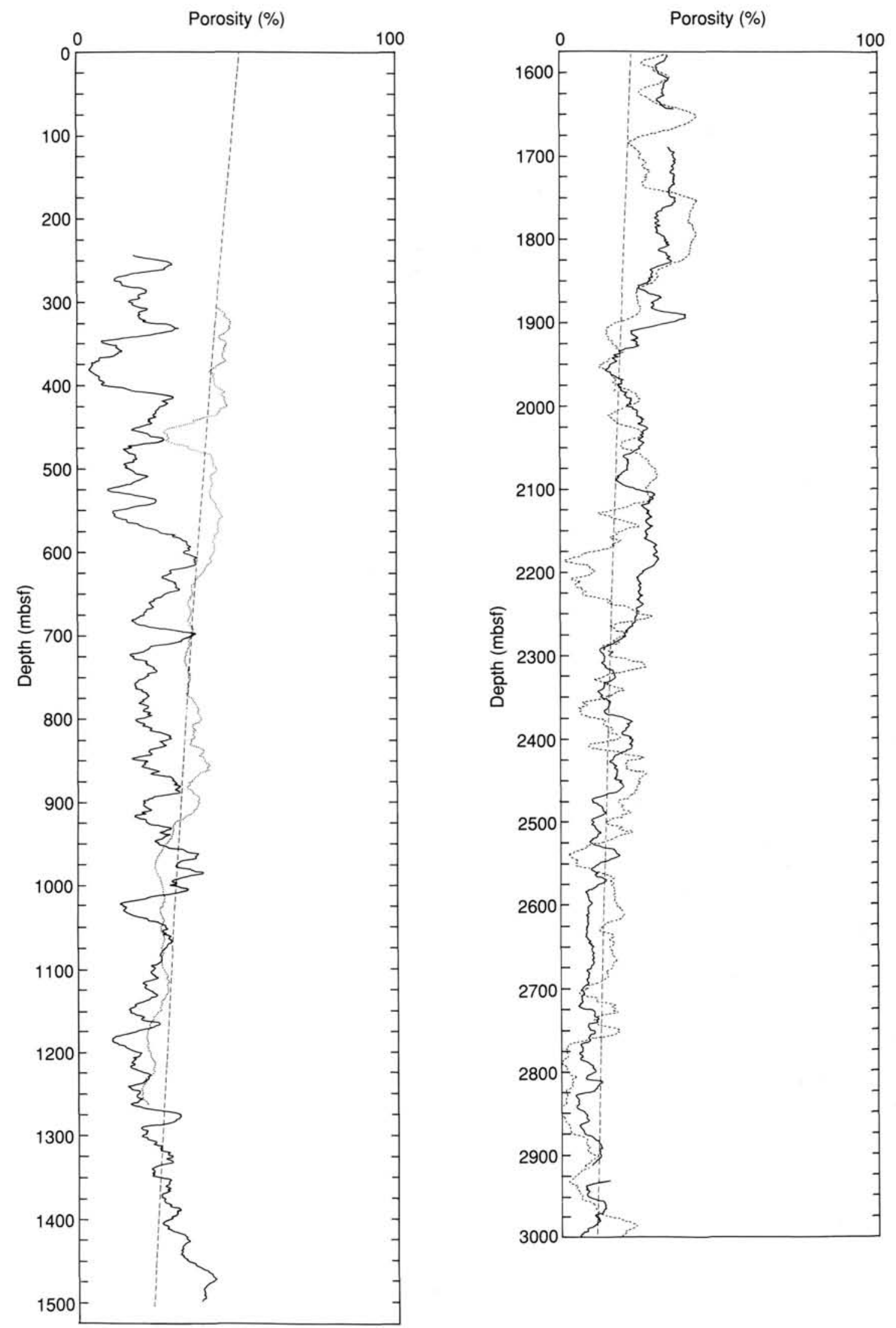

Figure 5. Corrected porosity logs from the top $3000 \mathrm{~m}$ of the Great Isaac well (neutron porosity indicated by a dashed line, and sonic porosity by a dotted line) and the Long Island well (solid line), along with the exponential curve-fit relationship for porosity with depth from Schmoker and Halley (1985). 


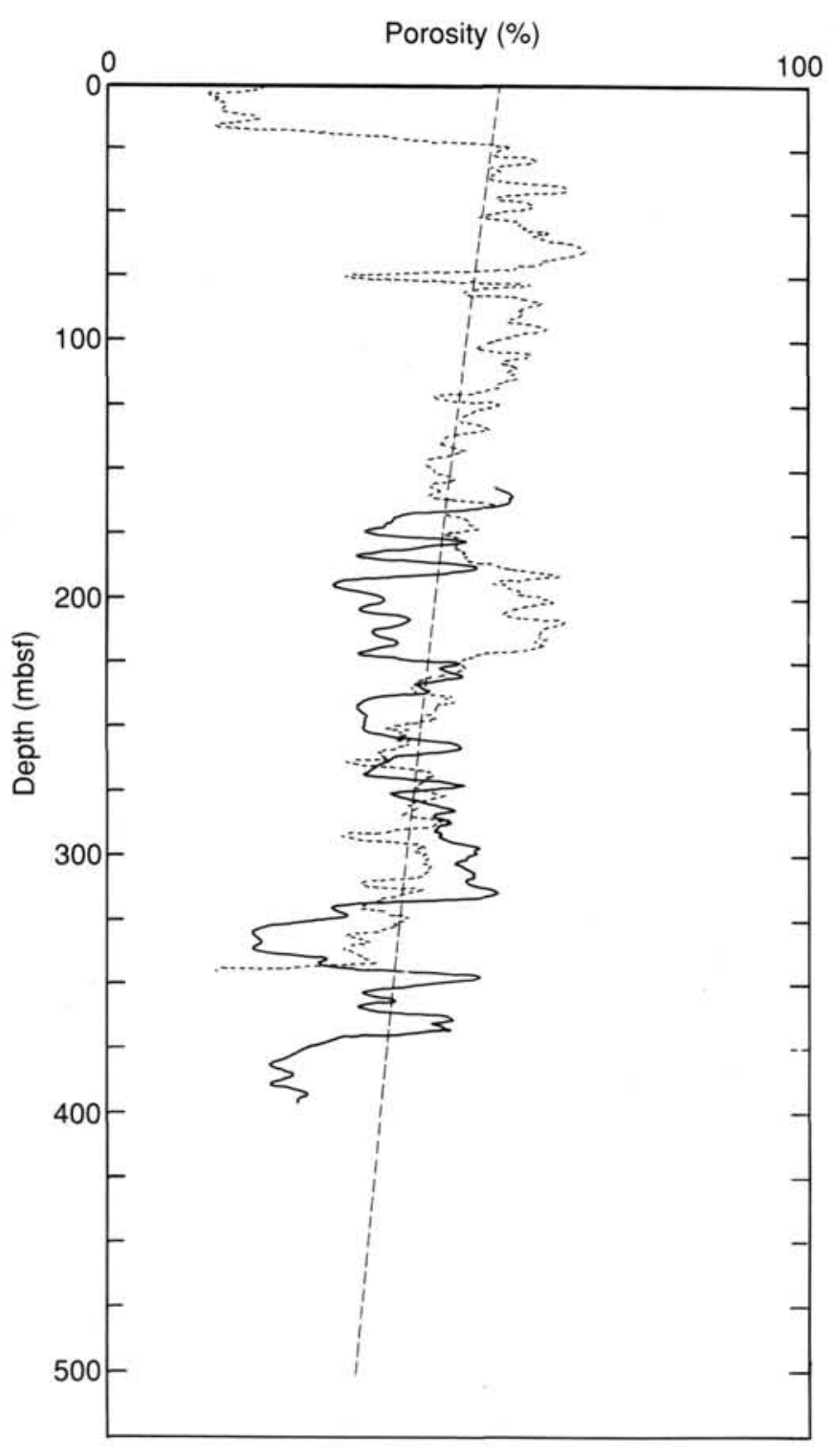

Figure 6. Corrected porosity logs from Holes 626D (long dashed line) and $634 \mathrm{~A}$ (solid line), along with the curve-fit porosity with depth relationship for Site 626 (short dashed line).

ever, at Great Isaac "tectonic" subsidence is still almost three times greater. If our subsidence curves are accurate, then some time since the middle Miocene, a significant ongoing tectonic event has buried Great Isaac in relation to the other locations. Given the continued position of Great Isaac on top of Great Bahama Bank, such an isolated tectonic event seems unlikely.

The actual source of this subsidence difference is in the original backstripping assumptions. We assumed that the relative water depth among the four sites remained constant since the late Oligocene. However, as demonstrated by Schlager et al. (this volume), Great Bahama Bank near the Great Isaac well has undergone significant progradation since the Miocene (Fig. 8). Clearly, this change in water depth must be taken into account. Schlager et al.'s discovery was the starting point for the following approach. Varying progradation rates over various time spans were applied to the subsidence data, with the bathymetric profile of the Straits of Florida west of Great Isaac (Malloy and Hurley, 1970) serving as the shape of the prograding bank edge. All models were consistent with Schlager et al.'s idea that Great

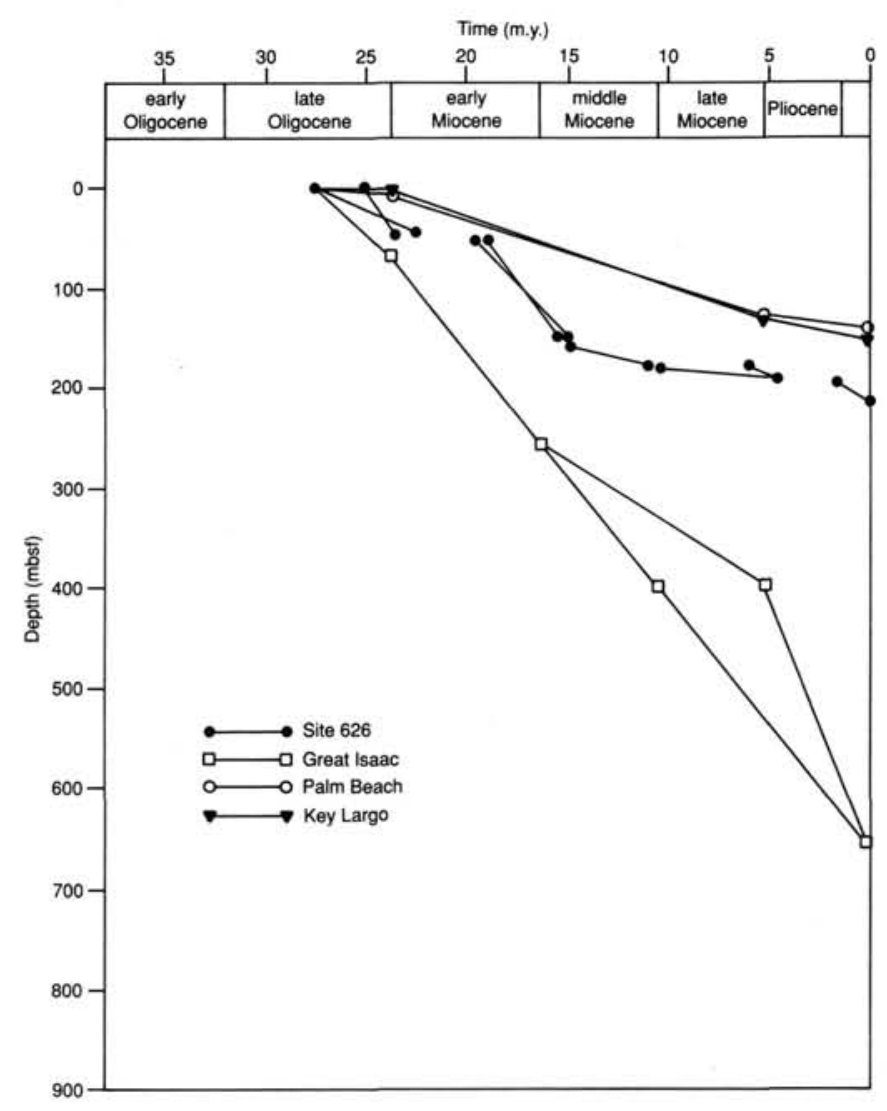

Figure 7. "Tectonic" subsidence curves for Site 626 and Great Isaac, Palm Beach, and Key Largo wells, based on the assumption of constant relative water depths at all four locations.

Isaac lay near the bottom of the bank slope at some time in the late Oligocene to early Miocene. Figure 9 shows the corrected "tectonic" subsidence curves for the Straits of Florida region along with three models of progradation and subsidence at Great Isaac. All three models give results that are consistent with subsidence at the other sites, indicating that the "tectonic" driving forces were basically the same throughout the region.

Subsidence curves for the region can only be brought into logically consistent agreement by providing for the continued westward progradation of Great Bahama Bank. This provides an independent confirmation of the evidence found by Schlager et al. (this volume). No evidence, either in the morphology or in the seismically derived structure of the Great Isaac region (Austin, Schlager, et al., 1986), exists to indicate the presence of the active faulting required to account for such anomalous subsidence. A change in water depth from a prograding bank, along with the necessarily increased sedimentation rates, provides the most logical explanation.

According to the results shown in Figure 9, the "tectonic" subsidence of the Straits of Florida region since the late Oligocene has been approximately $150 \mathrm{~m}$. This subsidence appears to have occurred at a fairly constant rate, except for a decrease in the middle Miocene. The observed subsidence is characteristic of subsidence related to the evolution of passive continental margins (Steckler and Watts, 1978) and does not indicate active faulting. While the progradation of Great Bahama Bank and the associated downwarping of the neighboring channel could provide a mechanism for the excess subsidence (approximately $75 \mathrm{~m}$ ) at Site 626, this greater "tectonic" subsidence at Site 626 is consistent with the idea that an underlying megabank is subsiding at a regionally uniform rate. However, the reader should keep in mind that the uncertainties associated with the progra- 


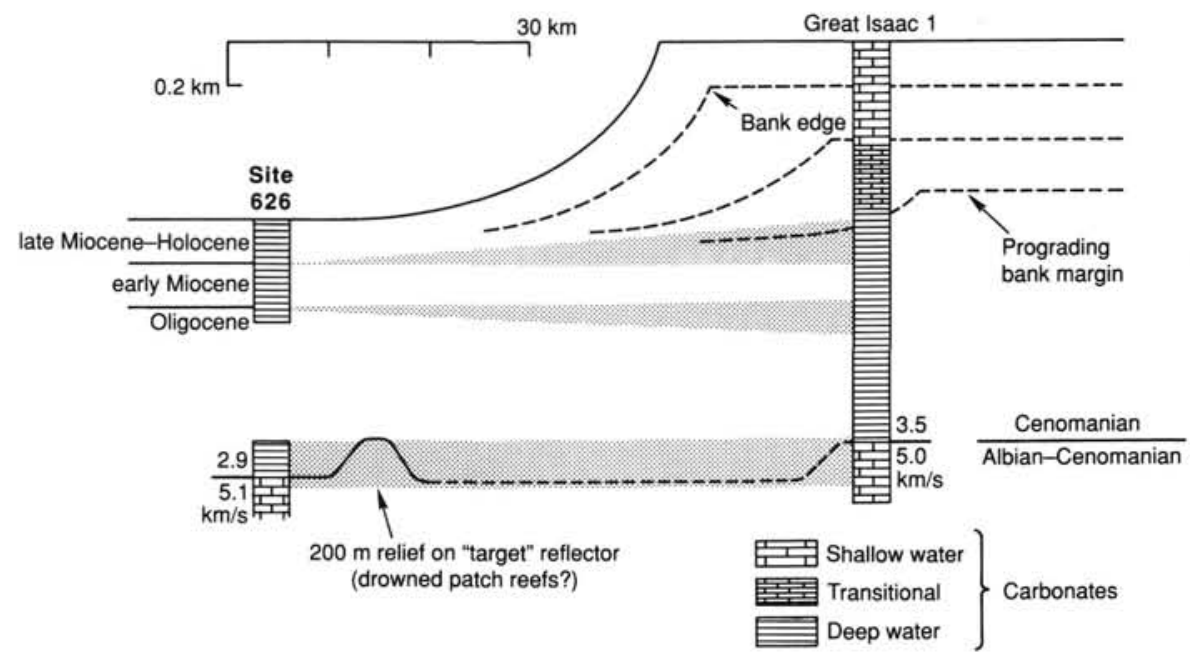

Figure 8. Correlation of stratigraphy sampled at Site 626 and at the Great Isaac well approximately $60 \mathrm{~km}$ to the northeast (after Austin, Schlager, et al., 1986). The Great Isaac section suggests that a shallow-water platform occupying what is now the northwestern corner of Great Bahama Bank drowned in the mid-Cretaceous. It was succeeded by a deep-water section until the Miocene, when shallow-water conditions again prevailed (to the present) (see Austin, Schlager, et al., 1986; Schlager et al., this volume; Austin et al., this volume). This observed succession suggests pronounced (at least tens of kilometers) lateral migration of bank margins through time.

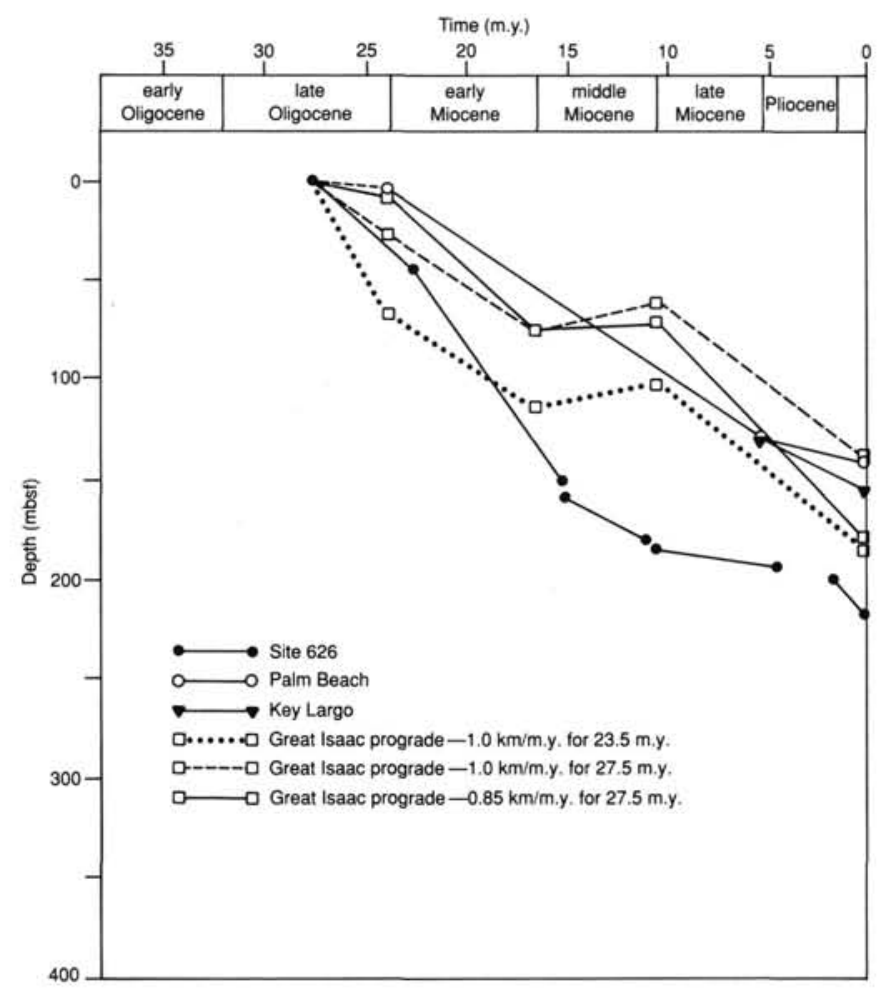

Figure 9. "Tectonic" subsidence at Site 626 and Palm Beach, Key Largo, and Great Isaac wells, with three models of progradation of Great Bahama Bank.

dation of Great Bahama Bank are great enough to account for the observed differences between Site 626 and the nearby banks.

On the basis of the modeling approach discussed previously, it is impossible to differentiate conclusively between the graben and the megabank hypotheses, but one possible consequence of the graben hypothesis has been eliminated. Given the fact that the subsidence over the past 28 m.y. shows no indication of ac- tive faulting around or across the Straits of Florida, it is unlikely that graben-bounding faults still have any control over the morphology of the Bahamas near the Straits of Florida. This result is consistent with recent seismic studies of the northwestern Bahamas (Sheridan et al., 1981; Eberli and Ginsburg, 1987; Austin et al., this volume). None of these surveys identified any form of post-Oligocene faults bounding the straits, either from new faults or from reactivated pre-Oligocene faults.

\section{STRUCTURE OF THE NORTHEAST PROVIDENCE CHANNEL: SYNTHETIC SEISMOGRAMS GENERATED FROM SITE 634 GEOCHEMICAL LOGS}

While the drilling program of Leg 101 resolved many of the problems associated with Bahamian geology (and carbonateplatform geology in general), the failure to reach the platform target at more than one location resulted in uncertainties regarding the form and extent of the mid-Cretaceous shallow-water platform. For the megabank hypothesis to hold true, the platform must have covered a large part of what is now the $\mathrm{Ba}$ hamas and South Florida and must not have existed as a number of small, isolated banks, which are characteristic of the postCretaceous history of the Bahamas (Eberli and Ginsburg, 1987). Clearly, valid seismic ties among the various drilling sites are necessary to remove stratigraphic uncertainties in the Bahamas, and, as part of this effort, reasonable correlations between seismic reflectors and drill-site stratigraphy are needed.

The creation of synthetic seismograms, based on acoustic impedance profiles generated from velocity and density logs of in-situ physical properties, is perhaps the most common method of establishing seismic and stratigraphic ties. The agreement between velocity logs and the velocities calculated using seismicreflection studies is often good. This is demonstrated for the Bahamas by a comparison of the interval velocities determined by Sheridan et al. (1981) for the edge of Great Bahama Bank near Great Isaac with a velocity log from the Great Isaac well (Fig. 10). Except for the section from 250 to $1150 \mathrm{~m}$, the curves match almost exactly. The reason for the discrepancy between seismically estimated velocities and sonic-log velocities in the upper section of the Great Isaac well is not clear. The relatively 


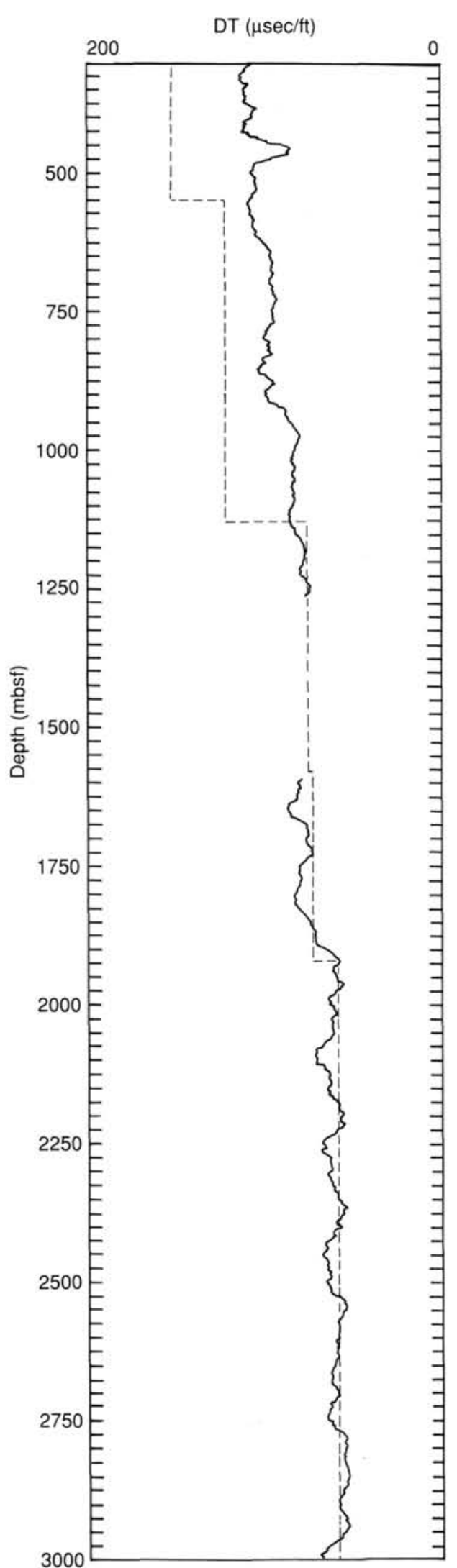

Figure 10. Slowness (labeled as DT) plot of a sonic-velocity log from the top $3000 \mathrm{~m}$ of the Great Isaac well, compared with slowness values used by Sheridan et al. (1981) for Great Bahama Bank near the Great Isaac well. high sonic velocities at Great Isaac indicate that lithification of these bank deposits proceeded at a fairly rapid rate. This result is consistent with the observation that only a small amount of intergranular cementation usually is required to cause a significant velocity increase in high-porosity sediments (Hamilton and Bachman, 1982). In carbonates, comparisons of sonic log-derived velocities with seismic velocities occasionally show similar discrepancies, and these discrepancies often are tied to the different spatial scales over which the two measurements are averaged (Serra, 1984). Borehole measurements are made at what is effectively a point in a lateral plane and are subject to local variations in lithology and physical properties typical of shallowwater carbonate environments. Thus, even where sonic-log measurements are available, it is important to find independent methods for estimating interval velocity. The synthetic seismogram technique described next is just such a method.

\section{Site 634}

Site 634 is a deep penetration site located near DSDP Site 98 in the Northeast Providence Channel (Austin, Schlager, et al., 1986; Paulus, 1972) and crossed by Lamont-Doherty Geological Observatory (LDGO) multichannel seismic line 94 (Sheridan et al., 1981; Fig. 11). Despite penetrating only $480 \mathrm{~m}$ and falling short of the inferred platform top, Hole 634A crossed two regionally prominent reflectors. The upper reflector, labeled in Figure 11, falls at $0.19 \mathrm{~s}$ sub-bottom and was interpreted by Sheridan et al. (1981) as the upper Eocene/upper Oligocene sequence boundary. Preliminary drilling results identified this reflector as either the Paleocene/Eocene contact or the top of the upper Campanian (Austin, Schlager, et al., 1986). The lower reflector, also shown in Fig. 11 and identified as a lower Eocene/ upper Eocene sequence boundary by Sheridan et al. (1981), falls at $0.295 \mathrm{~s}$ sub-bottom. Studies of the lithologies recovered at Site 634 (Fig. 2) indicated that this reflector occurs within the Campanian calciturbidite sequence (Austin, Schlager, et al., 1986).

Our motivation for constructing a synthetic seismogram for Site 634 was (1) to tie these regional reflectors to specific locations in Hole 634A and (2) to use the information gained from these sequence locations to extrapolate the results from Site 634 to other sites in the Bahamas. Unfortunately, core recovery was poor and drilling disturbance pervasive, which prevented generation of a seismogram based upon physical-properties measurements alone. Also, as a result of poor hole conditions, logging was limited to a set of geochemical tools that could measure through the drill pipe, in this case, a Schlumberger gamma-ray (GR), neutron porosity (CNL), and induced gamma-spectroscopy (GST) tool string (see Austin, Schlager, et al., 1986). However, the mineralogical and lithological information available from the GST technique helped determine in-situ bulk density and sonic velocity.

\section{Gamma Spectroscopy Tool and Determination of Lithology}

The GST is a logging tool that bombards a formation with high energy $(14 \mathrm{MeV})$ neutrons and digitally records the spectra of the returning gamma radiation. The digitized spectra are transmitted up the logging cable to an on-site computer, and relative elemental concentrations are determined by weighted leastsquares fits to the spectra. With the GST running continuously, the recorded spectra can be analyzed for the relative concentrations of six elements: iron, calcium, silicon, sulfur, hydrogen, and chlorine (Hertzog, 1978; Westaway et al., 1980). Knowledge of the concentrations of various elements does not, however, necessarily lead to accurate determinations of the values of certain physical properties, such as velocity and density. In a formation of complex lithologies, the transformation of elemental concentrations to mineral components and then to bulk litho- 


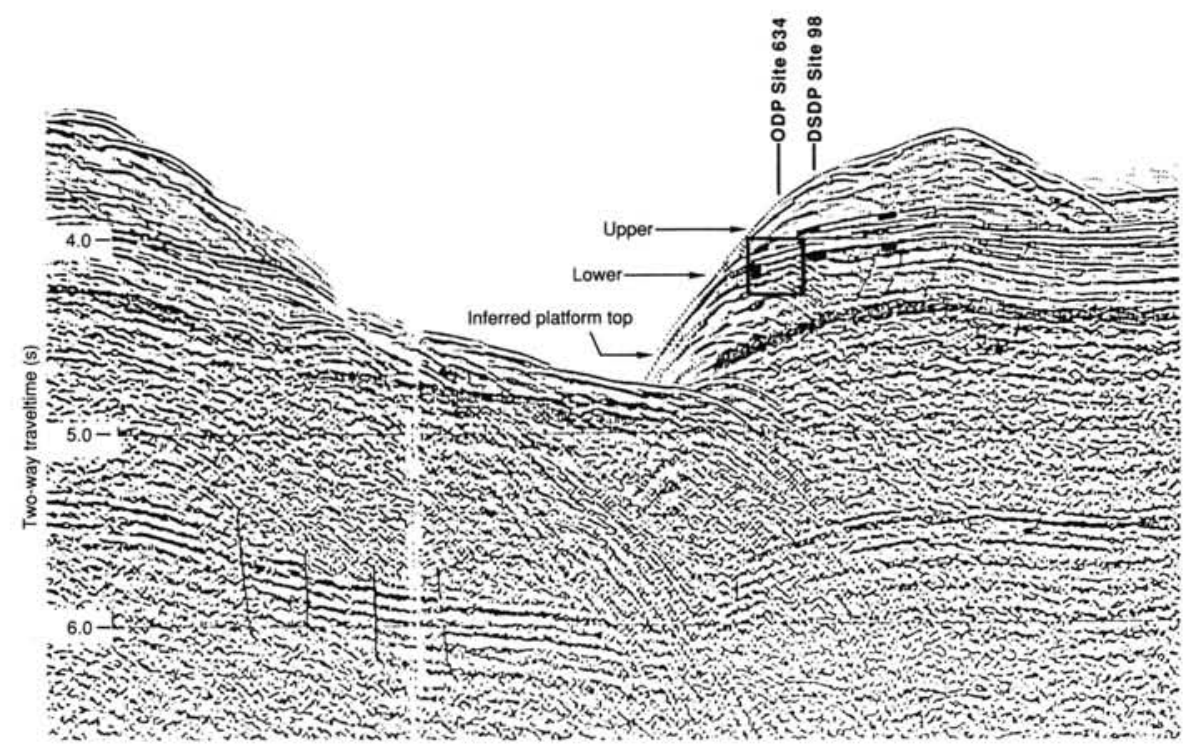

Figure 11. Location of Site 634 on LDGO line 94. The inferred platform top and the lower and upper reflectors are indicated, along with the section modeled with synthetic seismograms.

logic characteristics is not well understood. However, the relatively simple lithology at Site 634 limited the major formation components to calcite and chert. The calcium and silicon concentrations generated by the GST were interpreted as reflecting the relative amounts of calcite and chert, while the hydrogen concentration, a direct indicator of the amount of water in a clay-free formation, led to a GST-determined porosity, enabling us to correct these relative concentrations to absolute amounts.

GST-generated lithologies are based upon the statistical analysis of spectral counts. To obtain the accuracy necessary for mineralogical determinations, at least five passes must be made over the interval of interest (B. Everett, pers. comm., 1985). In Hole 634A, five GST passes were made over a section from 156 to 396 mbsf. After Leg 101, the tape records of these passes were combined for improved statistical accuracy and corrected for the effects of logging through the steel drill pipe. While core recovery over the logged interval was poor, some X-ray-diffraction measurements were available (Austin, Schlager, et al., 1986), which helped us to calibrate the GST-estimated quantity of silicon to the actual amount in the borehole. According to these GST results, numerous chert-rich layers occur in the logged section of Hole 634A (right-hand track of Fig. 12). The seven cores in the logged interval that recovered chert all fell at these layers, while those log-predicted chert intervals without recovered chert corresponded to cores of extremely poor recovery $(<5 \%)$. Thus, the recovery of chert provided an important confirmation of the qualitative accuracy of the GST-derived lithologies.

\section{Determination of Density and Velocity from Lithology}

Completion of shore-based computer processing and successful identification of chert-rich layers established that the GST provided accurate information about the amount of chalk, chert, and pore water in Hole 634A. The next step in the analysis was to translate these amounts into accurate estimates of bulk density and sonic velocity. Bulk density was derived easily. Given the known grain densities of calcite, chert, and seawater, a simple combination of log-derived volumes yielded a complete description of the variation of density with porosity and lithology. Figure 13 displays the results of this combination, along with shipboard measurements obtained from core samples; the GST-derived densities correspond well with the sampled densities. Estimating sonic velocity is another matter. A simple time/ average relationship (Wyllie et al., 1958) overestimates the velocity of high-porosity sediments, and the exact form of the correct velocity/porosity relationship has yet to be established theoretically (Goldberg et al., 1985). Physical-properties measurements of core-sample velocities would have been helpful for establishing an empirical relationship for this site, but relatively few data points existed, which precluded development of a statistically valid curve-fit.

In light of this lack of physical-properties data, two empirical relationships, one based on an in-situ study of a soft hemipelagic formation in the Baltimore Canyon Trough that consisted of approximately $40 \%$ calcite and $60 \%$ biogenic silica (Goldberg et al., 1985), and another developed from a detailed study of the properties of high-porosity pelagic sediments (Hamilton and Bachman, 1982), served as valuable lower limits for deriving the correct velocity relationship for Site 634 . Hamilton and Bachman's equation covers sediments in the upper $1 \mathrm{~m}$ of the ocean floor, so it is restricted to deposits with little intergranular cementation. Goldberg et al.'s equation covers sediment with a much higher percentage of silica than the sediment recovered at Site 634 . Since the sonic velocity of silica is lower than that of calcite, velocities from Site 634 should be greater than those found by Goldberg et al. (1985) for the same value of porosity.

With these lower limits and the time/average relationship serving as an upper limit, the Site 634 velocity/porosity curve was centered on the mean value given by the physical-properties measurements and given a slope matching that of the time/average equation (Fig. 14). More than $90 \%$ of the logging measurements fall in the middle of the line (between $40 \%$ and $60 \%$ porosity), where possible error from a difference in the slope of the velocity/porosity curve is small, and where most of the physical-properties measurements used to locate the midpoint of the line are centered. Since those zones in Hole 634A with porosities outside of the $40 \%$ to $60 \%$ range are thin zones that give rise to seismic reflectors through porosity-driven impedance contrasts, the resulting seismogram yields, at worst, an incorrect reflection amplitude. Thus, this error does not have a great effect on the two-way traveltime of the entire section, as could have occurred had we used the time/average equation.

After establishing velocity and density depth functions, we began to develop the synthetic seismograms. Two different com- 


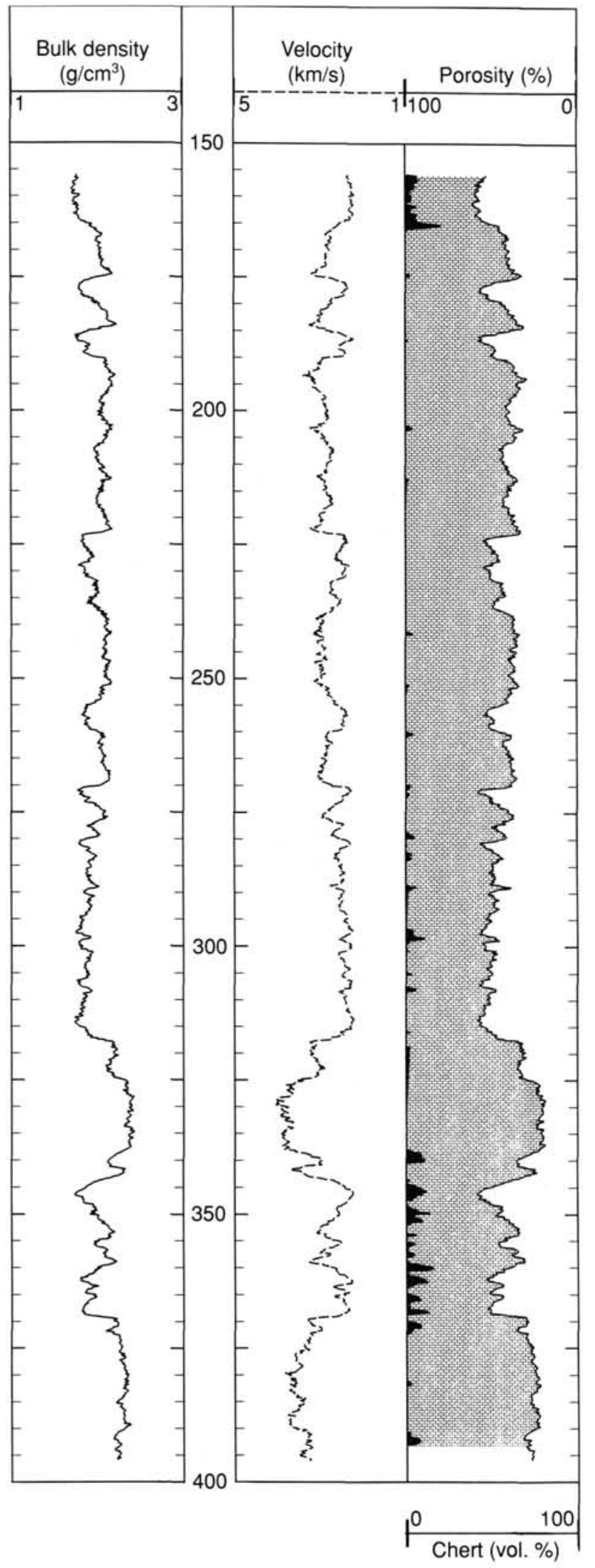

Figure 12. GST-generated density, velocity, and lithology curves from Hole 634A. Shaded sections in the far right track indicate (left to right) the volumetric proportions of chert (solid black), limestone (brick pattern), and pore water (clear), respectively. Depth in mbsf.

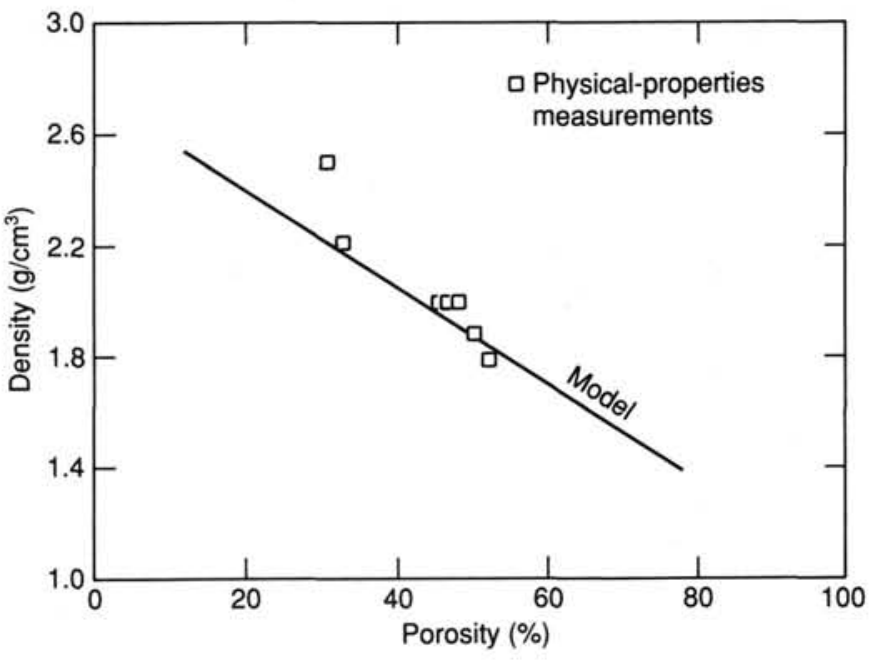

Figure 13. Comparison of the density/porosity relationship derived from GST measurements in Hole 634A with the physical-properties measurements from Site 634.

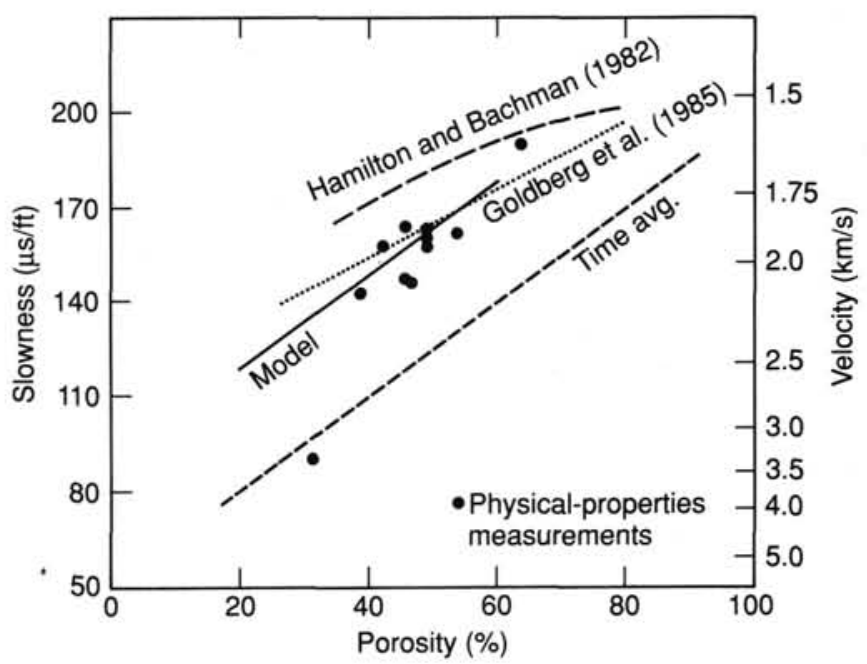

Figure 14. Plot of a modeled slowness/porosity relationship, relationships from Goldberg et al. (1985) and Hamilton and Bachman (1982), the time/average relationship for limestone, and the physical-properties measurements from Site 634 .

puter programs, VSP and SYN, were used to model the seismic structure near Site 634 . VSP uses given values of velocity, density, and $Q$ (a measure of attenuation) to produce a synthetic vertical seismic profile (Moos, 1984). Derived from a method developed by Ganley (1981), VSP takes a zero-phase wavelet of specified center frequency and bandwidth as its input and generates a seismogram by passing this wavelet through a model of discrete layers, accounting for absorption and dispersion through exponential decay with distance and including the effects of internal multiples. The second program, SYN, uses a one-dimensional convolution method to generate a synthetic seismogram from continuous velocity and density logs, with a Ricker wavelet of a given peak frequency as input. SYN includes internal multiples but not seafloor multiples. Previous study has shown that a one-dimensional convolution synthetic that includes internal multiples is virtually indistinguishable from a one-dimensional complete wave-equation synthetic (Arthur, Srivastava, et al., 1987). 
One of the motivations for using two different programs was to take advantage of the two different source functions, thus accounting for any possible source- or program-dependent effects. Characterizing the proper source signature is one of the most difficult problems encountered in synthetic modeling, as actual marine sources can be poor approximations of idealized wavelets (Neidell and Poggiagliolmi, 1977). Coverage of the dominant frequencies of the Conrad air-gun source used to shoot line 94 (Sheridan et al., 1981) was established by specifying a Ricker wavelet of $20 \mathrm{~Hz}$ for SYN and a zero-phase wavelet band-passed in the range of 8 to $32 \mathrm{~Hz}$ for VSP. If convincing synthetics could be generated using both wavelets, then the question of whether the synthetic source adequately simulated the actual seismic source could be answered.

The two synthetic seismograms are plotted with a blowup of part of the line 94 seismic section in Figure 15. Not only are the two regional reflectors (upper and lower) identified by Sheridan et al. (1981) visible, but the seismic section is duplicated almost exactly in both synthetics. While there is some difference in amplitude between the top of the lower reflector in the synthetics and the corresponding reflection in the seismic profile, it is clear that the synthetic models derived from geochemical measurements successfully duplicated results from line 94 .

Given the success of this duplication, we were able to identify the depths of the regionally identified reflectors in Hole 634A. Possible explanations for their existence as reflectors also can be inferred. The upper reflector occurs at approximately 165 mbsf, which, according to shipboard analyses (Austin, Schlager, et al., 1986), falls within Unit III, a nannofossil-rich chalk containing scattered nodules of chert. Comparison with the agedepth sequence (Fig. 2) indicates that this depth corresponds to the Paleocene/Eocene contact. On the GST log at this depth, there are sharp decreases in silica content and in porosity. This decreased silica is confirmed by XRD measurements, which show a $5 \%$ quartz content above this zone and $1 \%$ to $2 \%$ below it (Austin, Schlager, et al., 1986).

The top of the lower reflector, tentatively placed at $273 \mathrm{mbsf}$ by shipboard analysis, appears as a weak, but clear, arrival on the synthetics at approximately $280 \mathrm{mbsf}$, the top of a thick zone of relatively high porosity and scattered interbedded chert within the Campanian section of Hole 634A. The bottom of this zone produces another sharp reflection at $315 \mathrm{mbsf}$, where the chert disappears and porosity decreases to approximately $25 \%$ (Fig. 12). An abrupt change is seen again at $350 \mathrm{mbsf}$, with the reappearance of abundant chert and higher porosity (Fig. 12). All these changes fall in lithologic Unit IV, which is characterized by the alternation of nannofossil chalk with coarse, platform-derived sediments. These detrital limestones appear in a series of hard, bank-derived turbidites. Apparently, these last two reflections arise from the alternation of chert-rich, porous sediments with hard, chert-free, turbidite deposits. At this point, it is not clear why the weakest reflection in the seismogram corresponds to the top of the prominent lower reflector in the seismic section. Possibly, problems associated with the logging measurements, such as great changes in hole diameter, could have obscured the strength of the impedance contrast. Potential errors in the velocity/porosity relationship determined previously also could have played a role.

Despite these uncertainties, it appears that the reflections visible on line 94 can be tied directly to observable diagenetic and depositional processes within the sediment column. Since these processes vary greatly in spatial scale, the seismic connection at Site 634 illustrates the hazards associated with making regional seismic stratigraphic correlations without connecting seismic lines. A slight change in the depositional and erosional history of one locality can lead to significant errors in the inferences made through seismic interpretation, especially in the
Bahamas, where dramatic fluctuations in carbonate production are well documented (Schlager and Ginsburg, 1981). In carbonate environments, even deep-sea drilling provides no guarantee of a successful connection between seismic reflectors and their lithological and mineralogical causes. In this particular case, poor core recovery handicapped identification of these lithological changes and would have left the origin of the reflectors undiscovered if a series of geochemical and geophysical logging measurements had not been made in the hole.

\section{CONCLUSIONS}

Results of the two studies described here suggest the following conclusions regarding both the evaluation of the geologic structure of the Bahamas and the use of in-situ logging techniques to identify significant properties of complex carbonate environments.

\section{Bahamian Structure}

1. After appropriate corrections are made for sediment loading and westward progradation of Great Bahama Bank, the subsidence history of the Straits of Florida and its bounding banks reveals consistent subsidence and, thus, the underlying structural integrity of the northwestern Bahamas in the Straits of Florida region since at least the late Oligocene.

2 . The necessity of introducing the westward progradation of Great Bahama Bank to provide a logical subsidence history for the Great Isaac well serves to confirm the Schlager et al. (this volume) progradation model and suggests that this progradation may have started as early as the late Oligocene.

3. The synthetic seismograms from Site 634 in the Northeast Providence Channel provide clear and unambiguous information regarding the nature and origin of two prominent regional reflectors. The upper reflector falls at $165 \mathrm{mbsf}$, which corresponds to the Paleocene/Eocene contact. The top of the lower reflector falls at $280 \mathrm{mbsf}$ and arises as a result of the alternation of platform-derived deposits with deep-water channel deposits in a section of Campanian age. The frequent alternations within this section appear to account for neighboring reflections on the seismic line.

\section{In-Situ Techniques}

1. Both studies demonstrate that the highly variable facies patterns typical of carbonate environments make it difficult to interpret geophysical measurements in terms of geologic structures. Accurate compaction corrections require site-specific information about the variation of porosity with depth. The regional correlation of seismic profiles can only be accomplished with confidence if connecting seismic lines are available, preferably supplemented by the in-situ data provided by drilling and logging.

2. The success of the connection provided by the synthetic seismograms at Site 634 demonstrates for the first time that geochemical logs can provide accurate, quantitative information about the variation of velocity and density within a borehole, particularly when used in conjunction with measurements from core samples. This result not only confirms the accuracy of the induced gamma-ray-spectroscopy technique but also opens up a new application for geochemical logging. Since most geochemical logs can be run in cased holes or through drill pipe, synthetic seismograms can now be generated for scientific boreholes and old oil tests that lack open-hole sonic and density logs.

\section{ACKNOWLEDGMENTS}

We thank the officers and crew of the JOIDES Resolution (SEDCO/ BP 471) and particularly the SEDCO rig-floor crew for their help with our logging operations. Schlumberger engineers Jon Marvel and Bill 


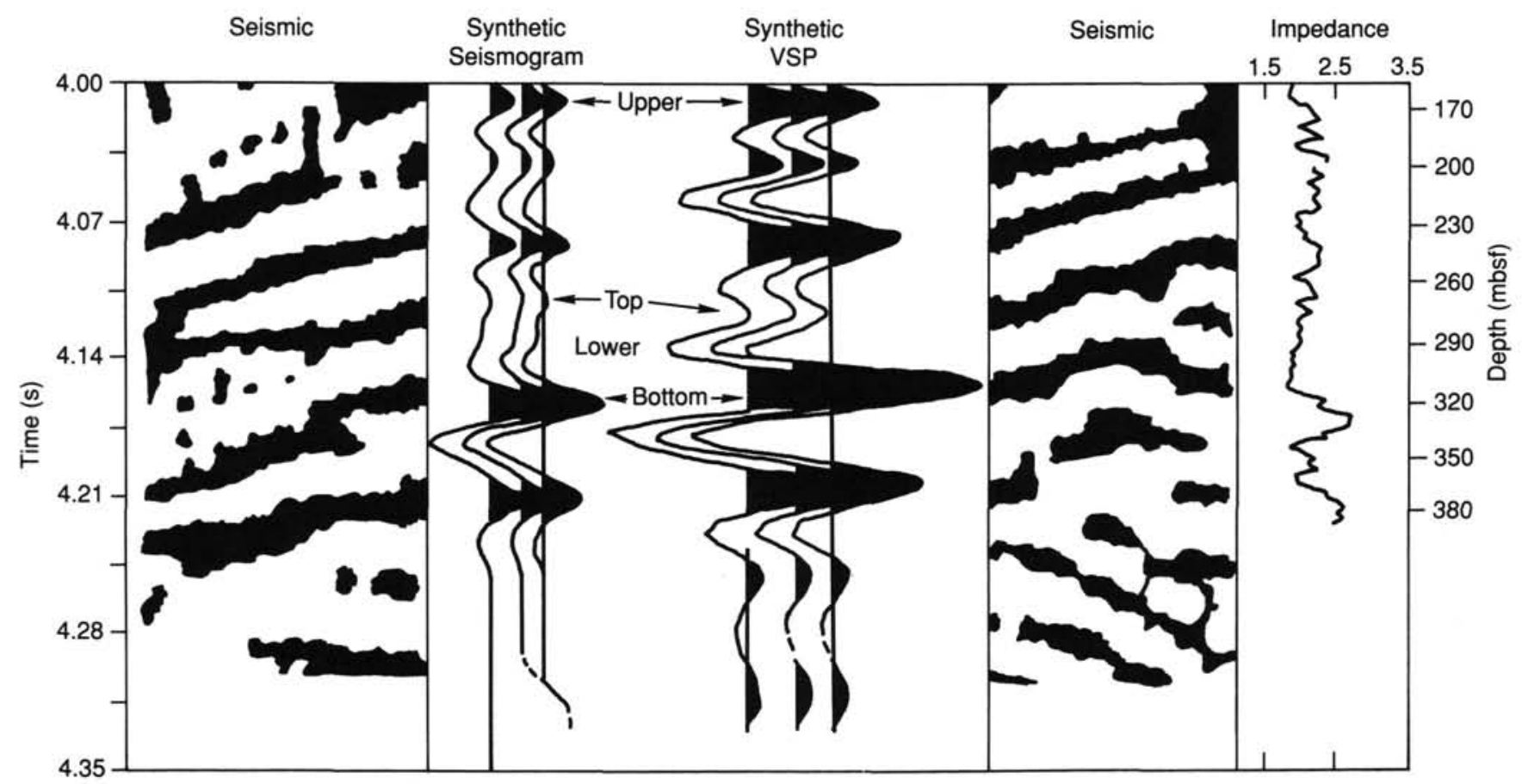

Figure 15. Expanded section from line 94 compared with the synthetics at Site 634 .

Parker deserve special thanks for their skill and determination during difficult logging conditions. Roy Dove at the Schlumberger Computing Center in Belle Chasse, Louisiana, provided invaluable help with the GST processing. This manuscript benefited from critical reviews by G. A. Barth, D. Moos, D. Goldberg, A. A. Palmer, D. Sawyer, W. Schlager, and an anonymous reviewer.

\section{REFERENCES}

Arthur, M. A., Srivastava, S. P., et al., 1987. Proc. ODP, Init. Repts., 105: College Station, TX (Ocean Drilling Program).

Austin, J. A., Jr., Schlager, W., et al., 1986. Proc. ODP, Init. Repts., 101: College Station, TX (Ocean Drilling Program).

Eberli, G. P., and Ginsburg, R. N., 1987. Segmentation and coalescence of Cenozoic carbonate platforms, northwestern Great Bahama Bank. Geology, 15:75-79.

Freeman-Lynde, R. P., Cita, M. B., Jadoul, F., Miller, E. L., and Ryan, W.B.F., 1981. Marine geology of the Bahamas Escarpment. Mar. Geol., 44:119-156.

Furrazola-Bermudez, G., Judoley, C. M., Mijailovskaya, M. S., Miroliubov, Y. S., and Solsona, J. B., 1964. Geologia de Cuba: La Habana (Min. Ind.).

Ganley, D. C., 1981. A method for calculating synthetic seismograms which includes the effects of absorption and dispersion. Geophysics, 46:1100-1107.

Goldberg, D., Wilkens, R. H., and Moos, D., 1987. Seismic modeling of diagenetic effects in Cenozoic marine sediments at Deep Sea Drilling Project Sites 612 and 613. In Poag, C. W., Watts, A. B., et al., Init. Repts. DSDP, 95: Washington (U.S. Govt. Printing Office), 589-600.

Goodell, H. G., and Garman, R. K., 1969. Carbonate geochemistry of Superior deep test well, Andros Island, Bahamas. AAPG Bull., 53: 513.

Hamilton, E. L., and Bachman, R. T., 1982. Sound velocity and related properties of marine sediments. J. Acoust. Soc. Am., 72:1891-1902.

Hertzog, R. C., 1978. Laboratory and field evaluation of an inelastic neutron scattering and capture gamma ray spectroscopy tool. Soc. Pet. Engr. Pap., 7430.

Maher, J. C., 1965. Correlation of Subsurface Mesozoic and Cenozoic Rocks Along the Atlantic Coast: AAPG Cross Section Publ., 3.

Malloy, R. J., and Hurley, R. J., 1970. Geomorphology and geologic structure: Straits of Florida, Geol. Soc. Am. Bull., 81:1947-1972.

Meyerhoff, A. A., and Hatten, C. W., 1974. Bahamas salient of North America. In Burke, C. A., and Drake, C. L. (Eds.), The Geology of Continental Margins: New York (Springer-Verlag), 429-446.
Moos, D., 1984. A case study of vertical seismic profiling in fractured crystalline rock. In Advances in Geophysical Data Processing: (JAI Press), 1:9-37.

Mullins, H. T., and Lynts, G. W., 1977. Origin of the northwestern Bahama platform: review and reinterpretation. Geol. Soc. Am. Bull., 88:1447-1461.

Neidell, N. S., and Poggiagliolmi, E., 1977. Stratigraphic modeling and interpretation-geophysical principles and techniques. In Payton, C. E. (Ed.), Seismic Stratigraphy-Applications to Hydrocarbon Exploration: AAPG Mem., 26:389-416.

Paulus, F. J., 1972. The geology of Site 98 and the Bahaman platform. In Hollister, C. D., and Ewing, J. I., Init. Repts. DSDP, 11: Washington (U.S. Govt. Printing Office), 877-897.

Schlager, W., and Ginsburg, R. N., 1981. Bahamas carbonate platforms-the deep and the past. Mar. Geol., 44:1-24.

Schmoker, J. W., and Halley, R. B., 1982. Carbonate porosity versus depth: a predictable relation for South Florida. AAPG Bull., 66: 2561-2570.

Serra, O., 1984. Fundamentals of Well-Log Interpretation: Amsterdam (Elsevier).

Sheridan, R. E., Crosby, J. T., Bryan, G. M., and Stoffa, P. L., 1981. Stratigraphy and structure of southern Blake Plateau, northern Florida Straits, and northern Bahama Platform from multichannel seismic reflection data. AAPG Bull., 65:2571-2593.

Spencer, M., 1967. Bahamas deep test. AAPG Bull., 51:263-268.

Steckler, M. S., and Watts, A. B., 1978. Subsidence of the Atlantic-type continental margin off New York. Earth Plan. Sci. Lett., 41:1-13.

Tator, B. A., and Hatfield, L. E., 1975. Bahamas present complex geology. Oil Gas J., 73(43):172-176; 73(44):120-122.

Van Hinte, J. E., 1978. Geohistory analysis-application of micropaleontology in exploration geology. AAPG Bull., 62:201-222.

Watts, A. B., Karner, G. D., and Steckler, M. S., 1982. Lithospheric flexure and the evolution of sedimentary basins. Trans. R. Phil. Soc. London, A305:249-281.

Westaway, P., Hertzog, R., and Plasek, R. E., 1980. The gamma spectrometer tool inelastic and capture gamma ray spectroscopy for reservoir analysis. Soc. Pet. Engr. Pap., 9461.

Wyllie, M.R.J., Gregory, A. R., and Gardner, G.H.F., 1958. An experimental investigation of factors affecting elastic wave velocities in porous media. Geophysics, 23:3.

Date of initial receipt: 14 November 1986

Date of acceptance: 10 April 1987

Ms 101B-155 